\title{
Fenilketonüri Hastalarının Sosyal Yaşamda Karşılaştıkları Zorluklar: Niteliksel Bir Araştırma
}

\author{
İsmail Mücahit Alptekin®, Funda Pınar Çakıroğlu@
}

Ankara Üniversitesi, Beslenme ve Diyetetik, Ankara, Türkiye

İsmail Mücahit Alptekin, Arş. Gör. Funda Pınar Çakıroğlu, Prof. Dr.

Iletişim:

Arş. Gör. İsmail Mücahit Alptekin Ankara Üniversitesi, Beslenme Ve Diyetetik, Ankara, Türkiye

Tel: +9003123812350

E-Posta: mucahit.alptekin@ankara.edu.tr

Gönderilme Tarihi : 280 cak 2018

Revizyon Tarihi ：06 Nisan 2018

Kabul Tarihi : : 11 Nisan 2018
ÖZET

Amaç: Protein kısıtlı diyet PKU tedavisinde temel faktördür. Ancak ömür boyu uyulması gereken sınırlı besin tüketimi, özel ürün tüketimi gibi diyet kuralları, PKU hastalarının sosyal yaşamlarını olumsuz etkileyebilmektedir. Bu araştırmada, doğuştan otozomal resesif bir hastalık olan PKU'nun bu hastalığa sahip bireylerin sosyal yaşamlarında neden olduğu sorunları ele almak amaçlanmıştır.

Araştırma Planı: Yarı-yapılandırılmış görüşme tekniği kullanılan bu niteliksel araştırmaya, PKU Aile Derneği aracılığı ile ulaşılan PKU tanısı almış bireyler ( $\mathrm{n}=63$ ) dahil edilmiştir. Öncelikle katılımcılara yaş, cinsiyet gibi demografik bilgileri, daha sonra diyetleri ile ilgili sorular, son olarak PKU ile yaşamanın ne hissettirdiği sorulmuştur.

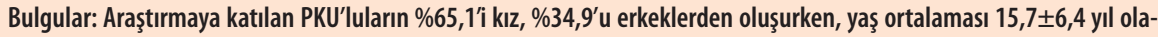
rak saptanmıştır. PKU'lu bireylerin büyük çoğunluğu $(\% 63,5)$ yeterli ve dengeli beslendiğini düşünmektedir. Katılımcıların çoğu yeterli ve dengeli beslenememe nedenini diyet nedeniyle sınırlı besinlerin tüketilmesi olarak belirtmiştir. Diyet ile ilgili kaçamak yapma durumuna PKU'lu bireyler \%61,9 ile hayır cevabını vermiştir. Kaçamak yaptığını belirten PKU'luların çoğu diğer besinleri çok arzuladıklarını belirtmişlerdir. PKU ile yaşamak konusunda yaşları küçük çocukların sosyal yaşamda daha fazla zorlandıkları sonucuna varılmıştır.

Sonuç: Bu araştırma, PKU'da oldukça yüksek prevalansa sahip olan ülkemiz açııından önemli ve özgün bir araştırmadır. PKU'lu bireylerin ve ailelerinin sosyal yaşamda karşılaştıkları sorunları ele alan araştırmaların artması gerekmektedir.

Anahtar sözcükler: Fenilketonüri, yaşam kalitesi, diyet

\section{CHALLENGES OF PATIENTS WITH PHENYLKETONURIA IN SOCIAL LIFE: A QUALITATIVE RESEARCH}

\section{ABSTRACT}

Objectives: Protein-restricted diet is a key factor in the treatment of PKU. However, dietary rules such as limited food/ special product consumption for a lifelong can adversely affect the life of PKU patients. In this study, it was aimed to investigate the challenges that PKU, an inherited autosomal recessive disease, causes in social life of PKU patients.

Study Design: This qualitative study used a semi-structured interview technique that included PKU patients ( $n=63$ ) who were reached by the PKU Family Association. Firstly, demographic information such as age and gender, then questions about the disease and diet, lastly how living with PKU felt were asked.

Results: $65,1 \%$ of patients are girls and $34,9 \%$ are men/boys and the mean age of the patients was $15,7 \pm 6,4$ years. The majority of the patients $(63,5 \%)$ think that they are fed adequately and equally. Most of the participants stated that the reason for lack of adequate-balanced nutrition is the consumption of limited foods due to diet. Patients gave the answer as no with $61,9 \%$ in case of dietary lapse. Many of PKUs who stated that they had a dietary lapse have indicated that they had a desire to other foods (or craved for other food). It was concluded that younger patients with PKU have more difficulties in social life.

Conclusion: This study is an important and unique study in our country that has a very high prevalence of PKU. There is a need for more studies about the difficulties that PKU patients and their families face in social life.

Keywords: Phenylketonuria, quality of life, diet 
D oğuştan otozomal resesif bir hastalık olan Fenilketonürinin (PKU), 12. kromozom üzerinde yer alan Fenilalanin Hidroksilaz (PAH) genindeki mutasyondan dolayı geliştiği ileri sürülmektedir (1). Bu gende meydana gelen mutasyon sonucunda Fenilalanin (Phe) aminoasidi Tirozin (Tyr) aminoasidine dönüşememekte ve kanda düzeyi yükselerek özellikle beyinde birikmesi ile kalıcı hasarlara yol açmaktadır. Metabolik hastalıklar arasında en sık görülen PKU'nun ülkemizde diğer ülkelerden daha fazla ortaya çıkmasına akraba evliliklerinin fazla olmasının neden olduğu düşünülmektedir (2).

PKU sadece biyokimyasal açıdan araştııılmamış, diyet kurallarına bağlı olarak PKU'lu bireylerin sosyal yaşamlarında karşılaştıkları sorunlar ve zorluklar üzerinde yeterli olmasa da çalışmalar yapılmıştır. Thimm ve ark. (2013) yaptığı bir araştırmaya, 50 çocuk ve adölesan ile aileleri dahil edilmiştir. PKU'lu bireyler ile sağlıklı akranları arasında bireyin kendi kendine değerlendirilen tüm bireysel boyutlardaki alanlarda yaşam kalitesi açısından farklılık bulunmamıştır. Fakat günlük işlerle ilgili yaşam kalitesinde (okul ya da anaokulu gibi), PKU hastası ebeveynlerinin sağlıklı çocuk ebeveynlerinden önemli ölçüde daha düşük skora sahip olduğu bulunmuştur. Fiziksel olarak iyi durumda olmasına rağmen, PKU'lu bireylerin ailelerinin, PKU'lu çocuklarının okul başarılarının düşük olmasından endişeli oldukları da belirtilmiştir (3). PKU'lu ebeveynler ile yapılan bir çalışmada, ebeveynlerin çocuklarının durumları ile iyi başa çıktıkları ancak yaşam kalitelerinin ve aile streslerinin anlamlı derecede normalin altında olduğu belirlenmiştir (4). PKU'lu bireyler ve aileleri ile PKU'nun bu bireyler üzerindeki etkilerinin değerlendirilmesi amacıyla yapılan bir çalışmada; PKU'lu bireylerin anket sonuçlarının iyi olduğu, fakat PKU ile baş etmenin duygusal etkileri gibi olumsuz yönlerinin olduğu gösterilmiştir (5).

Ülkemizdeki prevalansı dünya geneline göre yüksek olmasına rağmen PKU konusunda yeterli araştırma bulunmamaktadır. Özellikle PKU'lu bireylerin ve ailelerinin sosyal yaşamda karşılaştıkları sorunlar değerlendirilmelidir. Bu nedenle bu araştırmanın amacı PKU'lu bireylerin sosyal yaşamda karşılaştıkları zorlukları incelemeyi amaçlamaktadır. Bu araştırma daha sonraki kapsamlı araştırmalara da kaynak olacaktır.

\section{Gereç ve yöntem}

\section{Örneklem grubu}

Bu araştırma, PKU Aile Derneği aracılığı ile ulaşılan, PKU tanısı almış bireylerin dahil edildiği ve yarı-yapılandırılmış görüşme tekniği kullanılan tanımlayıcı niteliksel bir araştırma türüdür.
Araştırmanın örneklem grubunu; 9-11 yaş çocuklar $(n=20), 12-17$ yaş adölesanlar $(n=22)$ ve $18-35$ yaş yetişkinler ( $n=21$ ) olmak üzere 63 PKU'lu birey oluşturmaktadır.

Araştırmaya katılımda gönüllülük esas olarak alınmış olup PKU tanısı almış bireyler ile çalışma tamamlanmıştır. Bu araştırma için Ankara Çocuk Sağlığı ve Hastalıkları Onkoloji Eğitim ve Araştırma Hastanesi Klinik Araştırmalar Etik Kurulu'ndan 2016-004 protokol kodlu etik kurul onayı alınmıştır. Araştırmaya katıım gönüllülük esası doğrultusunda olduğu için katılmayı kabul eden bireylere çalışmanın detaylarının anlatıldığı ve iletişim bilgilerinin olduğu bilgilendirilmiş gönüllü olur formu imzalatılmıştır. Ayrıca araştırmanın sonuçları bölümünde bireylerin isimleri verilmeden sadece yaşları ve cinsiyetleri belirtilmiştir.

\section{Araştırma planı ve verilerin değerlendirilmesi}

Araştırmanın amacı kapsamında;

I. Demografik bilgiler: "Yaş, cinsiyet, ailedeki birey sayısı" sorularak elde edilmiştir.

II. Diyet ile ilgili durumlar: "Sizce yeterli ve dengeli besleniyor musunuz? Hayır ise nedenini söyler misiniz?", "Diyetiniz ile ilgili kaçamak yapıyor musunuz? Evet ise nedenini belirtir misiniz?" "Ev dışı yeme sıklığınız nedir?" ve "Ev dışı yemek yemenin zorluğu nedir?" soruları sorularak,

III. PKU ile yaşamak: "Sosyal yaşamda karşılaştığınız zorluklar nelerdir? PKU ile yaşamak nasıl bir duygudur?" şeklinde sorularak çalışma tamamlanmıştır (Tablo 1).

Tablo 1. Araştırmanın genel akış planı

\begin{tabular}{|c|c|}
\hline Sıralama & Verilerin değerlendirilmesi (sorular) \\
\hline 1. Basamak & $\begin{array}{l}\text { Demografik bilgiler }(n=63) \\
\text { - Yaş, cinsiyet, ailedeki birey sayısı }\end{array}$ \\
\hline 2. Basamak & $\begin{array}{l}\text { Diyete ait bilgiler }(n=63) \\
\text { - Yeterli ve dengeli beslenme, diyetle ilgili kaçamak } \\
\text { yapma, ev dışı yemek tüketiminin sıklığı ve zorluğu }\end{array}$ \\
\hline 3. Basamak & $\begin{array}{l}\text { PKU ile yaşamak }(n=54) \\
\text { - Sosyal yaşamda karşılaşılan zorluklar }\end{array}$ \\
\hline
\end{tabular}

Bireylerin verdikleri cevaplarda herhangi bir değişiklik yapılmamıştır, sadece bazı dilbilgisi düzeltmeleri yapılmıştır.

Araştırmanın ilk iki basamağındaki istatistiksel değerlendirmelerde PKU'lu bireyler yaş gruplarına ayrılmıştır. Araştırma verileri değerlendirilirken tanımlayıcı istatistiki değişkenler olan ortalama, standart sapma, alt-üst ve ortanca değerleri kullanılmıştır. Gruplar arasında istatistiksel 
farklılık olup olmaması belirlenirken Pearson Ki-Kare Bağımsızlık Testi kullanılmıştır. Tüm test sonuçları \%95,0 güven aralığında ve anlamlılık durumu $p<0,05$ düzeyinde değerlendirilmiştir. Araştırmadan elde edilen veriler Statistical Package for the Social Sciences (SPSS) paket programı ile değerlendirilmiştir.

Araştırmanın üçüncü basamağı, çalışmaya katılan bireylerden 9'unun çeşitli nedenlerle cevap vermek istememesi nedeniyle, 54 birey ile tamamlanmıştır. Bu bölümde bireylerin verdikleri ifadeler incelendikten sonra sonuçlar "PKU hakkında i; olumsuz düşüncede olanlar, ii; olumlu düşüncede olanlar ve iii; PKU'ya alışanlar" üç başlıkta incelenerek başlığa uygun olanların ifadeleri sonuçlar bölümünde verilmiştir.

\section{Bulgular}

Araştırmaya katılan bireylerin bazı demografik bilgileri Tablo 2'de verilmiştir. Çalışmaya katılan bireylerin çoğunluğunu kızlar oluşturmaktadır $(\% 65,1)$. Bireylerin ailesin-

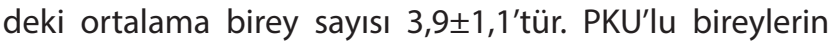
ortalama yaşı $15,7 \pm 6,4$ yıl olarak bulunmuştur.

Ev dışı yemek tüketim durumunda yaşa göre gruplar arasında istatistiksel bir farklılık bulunsa da $(p<0,05)$ ev dışı yeme sıklığında anlamlı farklıık bulunmamıştır. Çocukların \%50,0'sinin ev dışında yemek tükettiği ve bunun sıklığının en fazla \%35,0 ile "nadiren" olduğu belirlenmiştir. Adölesanların \%81,8'inin ev dışında yemek tükettiği ve tüketme sıklığının en fazla \%40,9 sıklığında "nadiren" olduğu belirlenmiştir. Ev dışında yemek tüketen yetişkinler \%90,5'dir ve bunun sıklığı en fazla \%42,9 ile "genellikle" olarak bulunmuştur (Tablo 3a). Ayrıca bireylerin \%42,9'u ev dışında yemenin zorluğunu çok zor, diğer \%42,9'u zor olarak belirtmiştir. Bu durum tüm yaş gruplarında benzer olarak bulunmuştur ( $p>0,05)$. (Tablo 3a).

PKU'lu bireylerin $\% 63,5^{\prime} i$ yeterli ve dengeli beslendiğini düşünmektedir (Tablo 3a). Yeterli ve dengeli beslenmeme nedeni sorulduğunda bireylerin verdikleri cevaplar detaylı olarak Tablo 3'de gösterilmektedir.

Diyet ile ilgili kaçamak yapma durumu sorulduğunda, PKU'lu bireylerin \%38,1'i kaçamak yaptığını belirtmiştir (Tablo 3b). Çocukların \%15,0'i, adölesanların \%50,0'si, yetişkinlerin \%47,6'sı diyetleri ile ilgili kaçamak yaptığını belirtmiştir $(p<0,05)$. Kaçamak yapma nedeni sorulduğunda katılımcıların verdikleri cevaplar detaylı olarak Tablo 3b'de gösterilmektedir.

Araştırmanın üçüncü basamağında bireylere sorulan "Sosyal yaşamda karşılaştığınız zorluklar nelerdir? PKU ile yaşamak nasıl bir duygudur?" sorusuna bireylerin $(n=54)$ verdikleri cevaplardan bazıları aşağıda verilmiştir.

PKU'lu bireylerin büyük bir çoğunluğu (37 birey), özellikle daha küçük yaşta olanlar, PKU ile yaşamanın olumsuz olduğunu dile getirmiştir;

"Bütün başka yiyeceklerin tadını bazen çok merak ediyorum, birileri yediğinde canım yemek istiyor, haksızlık olduğunu düşünüyorum (Kız/9Yaş)."

"Ürünlerimiz yurtdışından geliyor, burada seçenek az. Ben de markete gidip kendi ürünlerimden almak istiyorum (Erkek/10Yaş)."

Tablo 2. 1. Basamak: Katılımcılara ait bazı demografik bilgiler

\begin{tabular}{|c|c|c|c|c|c|c|c|c|c|}
\hline & & \multicolumn{2}{|c|}{$\begin{array}{c}9-11 \text { Yaş PKU'lular } \\
(n=20)\end{array}$} & \multicolumn{2}{|c|}{$\begin{array}{c}\text { 12-17 Yaş PKU'lular } \\
(n=22)\end{array}$} & \multicolumn{2}{|c|}{$\begin{array}{c}\text { 18-35 Yaş PKU'lular } \\
(n=21)\end{array}$} & \multicolumn{2}{|c|}{$\begin{array}{l}\text { Genel Toplam } \\
\quad(n=63)\end{array}$} \\
\hline & & $n$ & $\%$ & $n$ & $\%$ & $n$ & $\%$ & $n$ & $\%$ \\
\hline \multirow[t]{2}{*}{ Cinsiyet } & $\mathrm{KIz}$ & 11 & 55,0 & 12 & 54,5 & 18 & 85,7 & 41 & 65,1 \\
\hline & Erkek & 9 & 45,0 & 10 & 45,5 & 3 & 14,3 & 22 & 34,9 \\
\hline \multirow[t]{3}{*}{ Ailedeki birey sayısı } & $\bar{X} \pm S$ & \multicolumn{2}{|c|}{$3,9 \pm 0,7$} & \multicolumn{2}{|c|}{$3,9 \pm 1,1$} & \multicolumn{2}{|c|}{$3,9 \pm 1,2$} & \multicolumn{2}{|c|}{$3,9 \pm 1,1$} \\
\hline & Ortanca & \multicolumn{2}{|c|}{4,0} & \multicolumn{2}{|c|}{4,0} & \multicolumn{2}{|c|}{4,0} & \multicolumn{2}{|c|}{4,0} \\
\hline & Alt-Üst & \multicolumn{2}{|c|}{$3-6$} & \multicolumn{2}{|c|}{$3-7$} & \multicolumn{2}{|c|}{$1-6$} & \multicolumn{2}{|c|}{$1-7$} \\
\hline \multirow[t]{3}{*}{ Yaş } & $\bar{X} \pm S$ & \multicolumn{2}{|c|}{$10,2 \pm 0,6$} & \multicolumn{2}{|c|}{$13,3 \pm 1,1$} & \multicolumn{2}{|c|}{$23,5 \pm 5,1$} & \multicolumn{2}{|c|}{$15,7 \pm 6,4$} \\
\hline & Ortanca & \multicolumn{2}{|c|}{10} & \multicolumn{2}{|c|}{13} & \multicolumn{2}{|c|}{22} & \multicolumn{2}{|c|}{13} \\
\hline & Alt-Üst & \multicolumn{2}{|c|}{$9-11$} & \multicolumn{2}{|c|}{$12-15$} & \multicolumn{2}{|c|}{$18-35$} & \multicolumn{2}{|c|}{$9-35$} \\
\hline
\end{tabular}


Tablo 3A. 2. Basamak: Diyet ile ilgili durumlar

\begin{tabular}{|c|c|c|c|c|c|c|c|c|c|c|c|}
\hline & & \multicolumn{2}{|c|}{$\begin{array}{c}\text { 9-11 Yaş PKU'lular } \\
\text { (Çocuk) }(n=20)\end{array}$} & \multicolumn{2}{|c|}{$\begin{array}{l}\text { 12-17 Yaş PKU'lular } \\
\text { (Adölesan) }(n=22)\end{array}$} & \multicolumn{2}{|c|}{$\begin{array}{l}\text { 18-35 Yaş PKU'lular } \\
\text { (Yetişkin) }(n=21)\end{array}$} & \multicolumn{2}{|c|}{$\begin{array}{l}\text { Genel toplam } \\
\quad(n=63)\end{array}$} & \multirow[b]{2}{*}{$x 2$} & \multirow[b]{2}{*}{$p$} \\
\hline & & $n$ & $\%$ & $n$ & $\%$ & $n$ & $\%$ & $n$ & $\%$ & & \\
\hline \multirow{2}{*}{$\begin{array}{l}\text { Ev dışı yemek tüketimi } \\
\text { durumu }\end{array}$} & Evet & 10 & 50,0 & 18 & 81,8 & 19 & 90,5 & 47 & 74,6 & \multirow{2}{*}{9,78} & \multirow{2}{*}{0,007} \\
\hline & Hayır & 10 & 50,0 & 4 & 18,2 & 2 & 9,5 & 16 & 25,4 & & \\
\hline \multirow{5}{*}{ Ev dışı yeme sıklığı } & Çok sık & 2 & 10,0 & 3 & 13,6 & 2 & 9,5 & 7 & 11,1 & \multirow{5}{*}{10,89} & \multirow{5}{*}{0,213} \\
\hline & Genellikle & 2 & 10,0 & 6 & 27,3 & 9 & 42,9 & 17 & 26,9 & & \\
\hline & Nadiren & 7 & 35,0 & 9 & 40,9 & 7 & 33,3 & 23 & 36,5 & & \\
\hline & Çok nadir & 3 & 15,0 & 3 & 13,6 & 1 & 4,8 & 7 & 11,1 & & \\
\hline & Hiç & 6 & 30,0 & 1 & 4,5 & 2 & 9,5 & 9 & 14,4 & & \\
\hline \multirow{4}{*}{$\begin{array}{l}\text { Ev dışı yemek yemenin } \\
\text { zorluğu }\end{array}$} & Çok zor & 8 & 40,0 & 14 & 63,6 & 9 & 42,9 & 31 & 49,2 & \multirow{4}{*}{5,49} & \multirow{4}{*}{0,509} \\
\hline & Zor & 8 & 40,0 & 6 & 27,3 & 9 & 42,9 & 23 & 36,5 & & \\
\hline & Orta & 2 & 10,0 & 1 & 4,5 & 3 & 14,2 & 6 & 9,5 & & \\
\hline & Çok kolay & 2 & 10,0 & 1 & 4,5 & - & - & 3 & 4,8 & & \\
\hline \multirow{2}{*}{ Yeterli ve dengeli beslenme } & Evet & 12 & 60,0 & 11 & 50,0 & 17 & 81,0 & 40 & 63,5 & \multirow{2}{*}{4,59} & \multirow{2}{*}{0,101} \\
\hline & Hayır & 8 & 40,0 & 11 & 50,0 & 4 & 19,0 & 23 & 36,5 & & \\
\hline
\end{tabular}

Çünkü yeterli ürünler bulunmuyor.

İstediğim gıdaları bulamadığım ve gıdalardan tat alamadığım için.

Hastalı̆ı̆mdan dolayı seçici olduğum için.

Ürünleri istediğimiz gibi temin edemiyoruz.

Ürünlere ulaşamıyoruz ve çok pahalı ülkemizde yeterli ürün yok.

Fenilketonüri.

Yeterli ve dengeli Hastalı̆ı̆mdan dolayı.

beslenememe nedeni Kalsiyum, omega, demirden yoksun bir diyetimiz var.

Yemek seçtiğim için.

Her şeyi yiyemediğim için.

Ürünleri bulmakta zorluk çekiyoruz.

İstediğimizi yiyemiyoruz.

Öğünlerimi tamamlayamıyorum ve iştahsızıı̆ım da olduğu için.

Zamanım olmuyor. Dışarıda da yeterli çeşit yok.

Doymak için nişastalı gıdalara ağırlık veriyorum. Nişastanın şeker oranı yüksek vücuduma zarar veriyor. Kilo alıyorum.

*Pearson Ki-Kare Bağımsızlık Testi

Tablo 3B. 2. Basamak: Diyet ile ilgili durumlar

\begin{tabular}{|c|c|c|c|c|c|c|c|c|c|c|c|}
\hline & & \multicolumn{2}{|c|}{$\begin{array}{l}\text { 9-11 Yaş PKU'lular } \\
\text { (Çocuk) }(n=20)\end{array}$} & \multicolumn{2}{|c|}{$\begin{array}{l}\text { 12-17 Yaş PKU'lular } \\
\text { (Adölesan) }(n=22)\end{array}$} & \multicolumn{2}{|c|}{$\begin{array}{c}\text { 18-35 Yaş PKU'lular } \\
\text { (Yetişkin) }(n=21)\end{array}$} & \multicolumn{2}{|c|}{$\begin{array}{c}\text { Genel toplam } \\
\quad(n=63)\end{array}$} & \multirow[b]{2}{*}{ x2 } & \multirow[b]{2}{*}{$p$} \\
\hline & & $n$ & $\%$ & $n$ & $\%$ & $n$ & $\%$ & $n$ & $\%$ & & \\
\hline \multirow{2}{*}{$\begin{array}{l}\text { Diyetle ilgili kaçamak } \\
\text { yapma }\end{array}$} & Evet & 3 & 15,0 & 11 & 50,0 & 10 & 47,6 & 24 & 38,1 & \multirow{2}{*}{6,65} & \multirow{2}{*}{0,036} \\
\hline & Hayır & 17 & 85,0 & 11 & 50,0 & 11 & 52,4 & 39 & 61,9 & & \\
\hline
\end{tabular}

Arada sırada cips, kraker yiyorum.

Okula gittığim için arkadaşlarımdan kaçamak yapıyorum.

Ürünlerimiz çok az.

Sosyalleşmek için dışarıda yemek yerken bana uygun yemek bulmak gerçekten zor ancak kaçamağım patates kızartması ve makarnayla sınırlı.

Mecbur kaldığım zamanlarda ama nadir.

Diyet ile ilgili kaçamak Kendime uygun bir şey bulamadığım nadir zamanlarda kısıtılıardan daha çok yiyerek.

yapma nedeni Günlük miktardan fazlasını tüketiyorum.

Canım isteyince.

Ekmek ürününü yiyemiyorum yesem de doymuyorum.

Doymuyorum ve iştah açık. Bazen de dışarıda kendime uygun yemek bulamıyorum o nedenle.

Canım çekiyor.

Arada sırada cips kraker yiyorum.

Canım çok istiyor.

Pearson Ki-Kare Bağımsızık Testi 
"Her şeyin ölçülü, limitli olması çok zor. Ailem okulun menüsüne göre bana her öğlen yemek hazırlıyor. Her gün yemeğimi taşıyorum. Her gün menü planlama ile uğraşıyoruz (Kız/12Yaş)."

\section{"Çok zor yorucu ve üzücü (Erkek/12Yaş)."}

"PKU'lu yaşamak zor bir duygu mesela dışarıya çıktığımızda yiyecek bir şey bulamıyoruz (Erkek/13Yaş)."

"Çok zor dışarda yiyebileceğiniz sadece patates kızartması (Erkek/14Yaş)."

"Çok zor; lokantalar, marketler, parklar bizim için zor. Başkaları yerken siz bakıyorsunuz, size ikram edilen bir şeyi alamıyorsunuz ve çevreniz size bir başka sanki acıyorlar gibi bakıyorlar. Bu da çok rahatsız edici bir şey (Erkek/15Yaş)."

"Oldukça zor. Herkesten farklı olmak kolay değildir. Ben en çok da ileride çocuklarımda olma ihtimali yüksek olduğu için üzülüyorum, benim için diyetten başka yapacak bir şey kalmadıçünkü (Kız/18Yaş)."

"Hayat hep yasaklarla dolu... Çevrenizdekilere anlatamıyorsunuz. Eğitimsiz olduklarından bir kereden bir şey olmaz diyerek yasaklı ürünleri yedirmeye çalısııyorlar. Kısaca hayat yasak olanlar, kısıtlı serbest olanlar ve serbest olanlardan ibaret (Kı//19Yaş)."

"Zor ve kısıtı bir yaşam. Dışarıda yemek bulma sıkıntısı çok fazla (Kadın/21Yaş)."

"Çok kötü. Sürekli açıklama yapmak zorunda kalıyorum. Etraftakilerin saçma soruları ya da acımalarından bıktım. Dışarıdan yemekten bıktım ya salata ya da patates. Bir ilişki yaşamaktan korkuyorum. Hep yalnız kalacağımın farkındayım. Kısacası PKU ile yaşamak berbat bir şey (Kadın/21 Yaş)."

"PKU ile yaşamak zor. Insanlar yadırgıyor ve tepki almamak için hastalığımı gizliyorum. Karaciğer rahatsızlığı dediğimde bulaşıcı hastalıkmış gibi davranıyorlar. PKU hakkında bilgileri eksik olduğu için zeka özürlü muamelesi yapıyorlar. Zekam normal desem de kabul görmüyor... Dışarıda yiyecek bir şey bulamıyorum... PKU'nun tanıtılması önemli... (Kadın/23Yaş)."

Bazı PKU'lu bireyler PKU ile yaşamanın zor olsa da PKU'ya alıştıklarını (13 birey), yaşamlarının kolay olduğunu belirmişlerdir;

"Zor değil aslında, alıştım, ürünlerim kolay ve çabuk bulunsa daha iyi olur (Kız/10Yaş)."

"PKU'lu olmak çok kötü bir duygu değil ama ben de diyetimin olmasını istemezdim (Kız/11 Yaş)."
"Zor bir yaşam şekli. Okul okuduğum için dışardan besleniyorum. Yediğim sadece salata. Arada bir patates kızartması. Ama diyetimi bunca yıl bozmadığım için sağlıklı ve de mutluyum (Kı//13Yaş)."

"Çocukluktan yetişkinliğe geçtikçe PKU bir hastalık olmaktan daha çok yaşam tarzımı haline geliyor ve dışarı çıkmaya başladığımızda daha da çok durumun farkına varıyor ve zorlanıyoruz. Fakat genel olarak PKU ile yaşamak ürün yetersizliğinden ve bilinçsizlikten dolayı zor (Kız/20Yaş)."

"PKU ile yaşamak zaman zaman çok zorlukları olsa da benim hayatıma çok büyük güzellikler getirdi. Ayrıca önüme büyük hedefler koymama vesile oldu. PKU'yu ben hastalık olarak değil kesinlikle bir yaşam tarzı olarak görüyorum. PKU benim hayatıma daima güzellikler getirdi ancak yaptığım en ufak bir kaçamağın veya diyetime uyamadığım zamanlarda zekamın ve beynimin etkileniyor olma endişesini çok sık yaşıyorum. PKU ile ilgili beni üzen ve çok fazla endişelenmeme neden olacak tek kötü faktör bu. Dönem dönem bu endişe beni ortoreksiya nervosa düzeyine bile taşıyabiliyor (Kız/22Yaş)."

"PKU, çocukların yaşları itibariyle anlayamayacakları bir hastalık. Yetişkinler için daha anlaşılabilir. PKU bizim için bir yaşam biçimi olmalı. Ancak o zaman alışırız. PKU zordur ama bir çocuk için (Kız/22Yaş)."

"Hayatta daima bir savaş içinde kalmak gibi, ama alışıyorsun (Kız/23Yaş)."

"Biraz sabır gerektiriyor normal zamanda kolay olsa da özel zamanlarda yaş büyüdükçe evlilik hamilelik gibi olaylarda biraz daha zorlayıcı (Kadın/26Yaş)."

PKU'lu bireylerin çok az bir kısmı (4 birey) durumlarından oldukça memnun olduklarını dile getirmiştir;

"PKU yaşam boyu süregelen bir diyet biçimi, ben artık PKU'yu yaşam biçimi gibi gördüm. PKU benim en yakın arkadaşım gibi ve hiç kimseye anlatmaktan çekinmiyorum (Kız/18Yaş)."

"Bence keyif verici bir duygu. Yaşım gereği mutluluk veriyor bana, çünkü her zaman sağlıklı beslendiğimi düşünüyorum ve bu yüzden çok sıkıntı yaşamıyorum. Bazı kısıtı ve yasak olan ürünlerim var bunları da artık hayatım boyunca uyguluyorum. Zorluğunu evet/hayır desem de mutlaka görüyorum. Çünkü ben de bir PKU'lu gencim. Bir yere çıktığımda bir misafirliğe gittiğimde zorluğunu yaşıyorum ürün konusunda ağırlıklı olarak. Ama yine de PKU'lu olduğum için mutluyum, çünkü bu benim yaşam tarzım. Sağlıklı ve doğal besleniyorum. Özellikle bir insana bu durumumu izah etmek gururlu hissetmemi sağlıyor. Hem de çok... Çünkü orada bir insana 
bir bilgi veriyorsun. Belki de belli mi olur bir hayat veriyorsun. Hastalığımı herkesle paylaşmayı çok seviyorum ve gurur duyuyorum. Bundan bahsederken de her zamanda cümlelerimin sonunda 'Bir Damla Kan Hayat Kurtarır' diyorum. (Erkek/20Yaş)."

"Genellikle zorlanmasam da dışarda rahatça ne yiyeceğim diye düşünmeden yemek isterdim ve kısıtlamasız yemek yemek canım istediğinde çikolata yemek bazen arkadaşlarıma da sorun oluyorum gibi geliyor çok şükür anlayışlı bir çevrem var anlayışlı bir çevren oldun mu seni özel bile hissettiriyorlar (Kadın/25Yaş)."

"Benim için yaşam tarzı ve bu yaşam tarzı beni özel kişi olduğumu hissettiriyor. Ayrıca bir PKU'lu bir anne olarak da kendimi çok iyi hissediyorum (Kadın/35Yaş)."

\section{Tartışma}

Türkiye akraba evliliği oranının yüksek olması sebebiyle PKU prevalansı açısından birçok ülke arasında ilk sırada yer almaktadır (2). Özalp ve ark. (2001) yaptıkları bir çalışmada PKU insidansını Türkiye için 1:4200 olarak bulmuşlardır (6). Literatürde, PKU ile ilgili birçok çalışma bulunmaktadır; fakat prevalansı diğer ülkelere kıyasla çok yüksek olan ülkemizde yeterli çalışma bulunmamaktadır.

PKU'ya bağlı semptomların azalması ve PKU'lu bireylerin daha sağlıklı bir yaşam sürmeleri için proteinden kısıtlı diyet tedavisine sürekli uymaları gerekmektedir. Kısacası yaşam boyu proteinden kısıtlı bir diyet programı takip edilmelidir. Yapılan çalışmalarda diyet kurallarına uyan bireylerde semptomların daha nadir olduğu ve bireylerin normal bir yaşam sürdükleri belirtilmektedir $(7,8)$. PKU'lu bireylerin evleri ziyaret edilerek, onlara bakan bireylere evlerinde eğitim verilmesinin çocuklarının kan Phe düzeylerine etkisine bakılan ülkemizdeki sınırlı sayıdaki araştırmaların birinde, 2-12 yaş aralığındaki 36 PKU'lu çocuğun aileleri evlerinde ziyaret edilmiştir. Detaylı bir eğitim verildikten sonra 1, 4, 12, 24 ve 48 hafta sonra PKU'lu bireylerin kan Phe düzeyleri kontrol edilmiştir. Ziyaretlerden 1 ve 4 hafta sonra PKU'lu bireylerin kan Phe düzeylerinde düşüş olduğu, 1. hafta sonundaki verilerin anlamlı derecede düşük olduğu saptanmıştır (9).

PKU'lu bireyler ve aileleri uygulanan diyetin yaşam boyu sürdüğü, çeşitli kısıtlamalara sahip olduğu ve özel ürün kullanımı gibi uygulamalar gerektirdiği için sosyal yaşamda çeşitli zorluklar ile karşılaşabilmektedirler (10). Ancak PKU'lu bireylerin ve PKU'lu çocuğa sahip ailelerin Phe kısıtlı diyetleri ve PKU ile ilgili günlük yaşamda karşılaştıkları sorunları ele alan araştırmalar oldukça yetersizdir. Sosyal durumlara yönelik bir ölçeğin kullanıldığı çalışmada, PKU'luların sosyal-bilişsel olarak eksikliklerinin olduğu sonucuna varılmıştır (11).

Çalışma sonuçları arasında yer alan diyet ile ilgili kaçamak yapma durumunun, PKU'luların ev dışında daha fazla zaman geçirmesinden, çeşitli sosyal ortamlarda bulunmalarından kaynaklandığı düşünülmektedir. Çünkü bireylerce dışarıda görülen yiyeceklere olan arzu genel olarak belirtilmiştir. Vegni ve ark. (2009) yaptıkları yaşa bağlı nitel bir çalışmaya 47 PKU'lu (8-23 yaş) birey dâhil etmiştir. Yaşa bağlı olarak PKU'luların sağlıklı oldukları fakat sosyal ortamda sıkıntı yaşadıkları ve hastalık ile ilgili bilgi düzeylerinin geliştirilmesi gerektiği sonucuna varmışlardır (12).

Bu çalışmada, PKU'lu bireylerin diyetlerinde en fazla yasak ürünler olmasından dolayı zorlandıkları, diğer besinlerin tadını merak ettikleri, okul, arkadaş ortamı gibi sosyal ortamlarda diyetleri yüzünden zorlandıkları, diyetin zorluklarına alışıldığı ancak diğer insanlara PKU'yu anlatmanın zor olduğu çıktılarına ulaşıımıştır. Ayrıca PKU ile yaşamak konusunda, PKU'lu bireylerin yaş artışı ile birlikte PKU ile yaşamaya alıştıkları belirlenmiştir. Yaşları 8-23 arasında olan PKU'luların dâhil olduğu ve yaşam tecrübelerinin değerlendirildiği nitel bir çalışmada, PKU'luların yeterli bilgi düzeyine sahip olmadıkları, kendilerini hasta gibi görmedikleri, yaşam kalitelerinin ise özellikle diyetleri nedeniyle olumsuz etkilendiği saptanmıştır (13). Çalışmamızda daha küçük yaştaki PKU'luların diyette yer almayan besin istekleri, diyetteki yasaklar konusunda zorlandıkları belirlenmiştir. Daha büyük yaşta olanların ise PKU ile yaşamanın oldukça zor olmasına rağmen PKU'nun daha fazla benimsediği, hastalıktan ziyade yaşam tarzı olarak gördüğü, ama diğer insanlara anlatma gereği duyma konusunda zorlandıkları sonucuna varılmıştır.

Sonuç olarak, ülkemize özgü profillerin çıkarılabilmesi ve PKU'lu bireylere destek olabilmesi açısından çalışmanın sonuçları önem taşımaktadır. Ülkemizdeki PKU'lu bireylerin yaşam kalitelerinin değerlendirilmesine yönelik yeterli bilimsel çalışma bulunmamaktadır. PKU'lu bireylerin diyetlerinden dolayı sosyal yaşamda karşılaştıkları sorunları elen alan niteliksel araştırmalara ihtiyaç vardır.

Teşekkür: PKU'lu bireylere ulaşılması konusunda değerli yardımlarından dolayı PKU Aile Derneği başkanı Sayın Deniz Yılmaz Atakay'a ve araştırmaya katılan tüm PKU'lu bireylere teşekkür ederiz. 


\section{Kaynaklar}

1. Santos LL, Fonseca CG, Starling ALP, Januário Jn, Aguiar MJB, Peixoto MGCD, Carvalho MRS. Variations in genotype-phenotype correlations in phenylketonuria patients. Genet Mol Res 2010;9:1-8. [CrossRef]

2. Williams RA, Mamotte CDS, Burnett JR. Phenylketonuria: An Inborn Error of Phenylalanine Metabolism. Clin Biochem Rev 2008;29:31-41. Erişim: https://www.ncbi.nlm.nih.gov/pmc/articles/PMC2423317/

3. Thimm E, Schmidt LE, Heldt K, Spiekerkoetter U. Health-related quality of life in children and adolescents with phenylketonuria: unimpaired $\mathrm{HRQ}$ oL in patients but feared school failure in parents. J Inherit Metab Dis 2013;36:767-72. [CrossRef]

4. Fidika A, Salewski C, Goldbeck L. Quality of life among parents of children with phenylketonuria (PKU). Health Qual Life Outcomes 2013;11:54-63. [CrossRef]

5. Bosch AM, Burlina A, Cunningham A, Bettiol E, Moreau-Stucker F, Koledova $E$, et al. Assessment of the impact of phenylketonuria and its treatment on quality of life of patients and parents from seven European countries. Orphanet J Rare Dis 2015;10:80-94. [CrossRef]

6. Özalp I, Coşkun T, Tokatlı A, Kalkanoğlu HS, Dursun A, Tokol S, et al. Newborn PKU screening in Turkey: at present and organization for future. Turk J Pediatr 2001;43:97-101.

7. Evans S, Daly A, Chahal S, Macdonald J, Macdonald A. Food acceptance and neophobia in children with phenylketonuria: a prospective controlled study. J Hum Nutr Diet 2016;29:427-33. [CrossRef]
8. Crujeiras V, Aldamiz-Echevarria L, Dalmau J, Vitoria I, Andrade F, Roca l, et al. Vitamin and mineral status in patients with hyperphenylalaninemia. Mol Genet Metab 2015;115:145-50. [CrossRef]

9. Gökmen-Özel H, Büyüktuncer Z, Köksal G, Kalkanoğlu-Sivri HS, Coşkun T. Home visits in phenilketonuria: a 12-month longitudinal study. Turk J Pediatr 2011;53:149-53.

10. Camp KM, Parisi MA, Acosta PB, Berry GT, Bilder DA, Blau N, et al. Phenylketonuria Scientific Review Conference: state of the science and future research needs. Mol Genet Metab 2014;112:87-122. [CrossRef]

11. Jahja R, Van-Spronsen FJ, De Sonneville LM, Van Der Meere JJ, Bosch $A M$, Hollak CE, et al. Social-cognitive functioning and social skills in patients with early treated phenylketonuria: a PKU-COBESO study. J Inherit Metab Dis 2016;39:355-62. [CrossRef]

12. Vegni E, Fori L, Riva E, Giovannini M, Moja EA. How individuals with phenylketonuria experience their illness: an age-related qualitative study. Child Care Health Dev 2009;36:539-48. [CrossRef]

13. Di Ciommo V, Forcella E, Cotugno G. Living with phenylketonuria from the point of view of children, adolescents, and young adults: a qualitative study. J Dev Behav Pediatr 2012;33:229-35. [CrossRef] 